\title{
Outcomes of the 9th EGU Plinius Conference on Mediterranean Storms (2007)
}

\author{
A. Mugnai ${ }^{1}$, F. Guzzetti ${ }^{2}$, and G. Roth $^{3}$ \\ ${ }^{1}$ Istituto di Scienze dell' Atmosfera e del Clima, Consiglio Nazionale delle Ricerche, Roma, Italy \\ ${ }^{2}$ Istituto di Ricerca per la Protezione Idrogeologica, Consiglio Nazionale delle Ricerche, Perugia, Italy \\ ${ }^{3}$ Dipartimento di Informatica, Sistemistica e Telematica, Università degli Studi di Genova, Genova, Italy
}

The 9th EGU Plinius Conference on Mediterranean Storms (Plinius-9 Conference, hereafter) was held on 1013 September 2007 in Varenna, Italy (http://meetings. copernicus.org/plinius9). It was the ninth in a series of topical conferences established in 1999 by the Interdisciplinary Working Group on Natural Hazards of the former European Geophysical Society (EGS). The original aim of the Plinius conference-series was to provide an opportunity for in-depth, multidisciplinary discussion on multiple aspects of natural hazards and risk, and specifically those associated to severe storms in the Mediterranean region. The idea was fertile, and the Plinius conference-series is a recognized forum for discussing advancements in the understanding of extreme events and related hazards in the Mediterranean region, including floods, landslides, coastal erosion, hailstorms, and sea waves.

The conference was held at the International Congress Centre Villa Monastero. The selection of the site was based on several motivations. Villa Monastero is a superb monastery and patrician abode on the shore of Lake Como, and an ideal venue for organizing a meeting. In addition, the roman writer, scientist, and naturalist Gaius Plinius Secundus, better known as Plinius Maior (Pliny the Elder), to whom the conference-series is dedicated, was born in Como.

When we planned the Conference, we decided to propose to the community an opportunity for a critical discussion on recent scientific and technological advancements related to Mediterranean storms. Accordingly, we organized the Conference programme around a set of topics addressing: (a) the nature and physical processes related to extreme precipitation events, (b) their expected alterations associated with the foreseen climate changes, (c) the techniques used to observe,

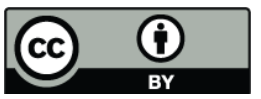

Correspondence to: A. Mugnai (a.mugnai@isac.cnr.it) monitor, and forecast the storms, (d) the impact of the storms, with the emphasis on damaging floods, landslides and coastal waves, and (e) the socio-economical aspects of damaging storms. We invited 25 experts, who had contributed to previous Plinius conferences, to be part of the Scientific Committee and to help convene fourteen different sessions. We selected specialists for nine keynote addresses.

We can say that the Plinius-9 Conference was a success. This is shown by the considerable number of abstracts submitted (170), by the attendance of 137 scientists from Europe, Middle East, Australia and the United States, and by the many papers that have resulted from the Conference.

This special issue of "Natural Hazards and Earth System Sciences" (NHESS, http://www.nat-hazards-earth-syst-sci. net/special_issue81.html) contains 18 papers that are based on presentations given at the Plinius-9 Conference. Noteworthy, 18 additional papers - including the two presentations (Hashino, 2008; Yan et al., 2008) that received the Med-Storm Prize for Young Researchers - are published in a twin special issue of "Advances in Geosciences" (ADGEO, http://www.adv-geosci.net/17/index.html). In the following, we summarize the content and main results of the papers published in the two joint special issues.

Through the analysis of individual meteorological events, or of catalogues of meteorological events in a period, a few authors discuss the nature and physical processes associated with storms in the Mediterranean area.

Miglietta and Regano (2008) use numerical modelling to investigate a heavy rainfall event that resulted in catastrophic flash flooding in Apulia, southern Italy, on 22 October 2005. Through numerical modelling, Fantini and Malguzzi (2008) study the initiation and the evolution of symmetric instability in saturated and supersaturated conditions. Nicolaides et al. (2009a) describe the meteorological characteristics of a baroclinic depression that affected Cyprus on 6 November 2005 resulting in extreme weather conditions.

Published by Copernicus Publications on behalf of the European Geosciences Union. 
Houssos et al. (2008) study the main synoptic conditions associated with extreme rainfall events in Greece in the period 1970-2002, clustering the different atmospheric circulation patterns. Federico et al. (2008) use numerical modelling and ground-based rainfall measurements for the period 1999-2007 to study the atmospheric circulation patterns associated with heavy rainfall events in Calabria, southern Italy. Michaelides et al. (2008) analyse a catalogue of hailstorm events in Cyprus during the period 1996-2005, and group the events in two clusters based on synoptic, dynamic and thermodynamic characteristics. In a numerical sensitivity study, Hashino (2008) investigates the microphysical effects of the Saharan dust on an orogenic thunderstorm that hit Genoa, Italy, on 27 September 1992.

Other authors discuss the results of investigations aimed at establishing the effects of climate change on Mediterranean storms, chiefly through numerical modelling.

Costa et al. (2008) use a stochastic space-time numerical technique in conjunction with daily rainfall measurements from all available ground stations in southern Portugal for the period 1940-1999, to produce annual gridded datasets of an extreme precipitation index. The purpose is to explore long-term trends of extreme rainfall and to assess the variation with time in the relationship between local elevation and extreme precipitation. Durão et al. (2009) exploit the same database of daily rainfall measurements for the 1960-1999 period within a geostatistical technique, to study the spatial and temporal statistics of two extreme precipitation indices in southern Portugal. The analysis of the time series does not reveal a temporal trend, but indicates that the precipitation regime in the considered region has become increasingly homogeneous. Mehta and Yang (2008) use a catalogue of precipitation products obtained by the joint NASA-JAXA Tropical Rainfall Measuring Mission (TRMM) to perform a climatological study of rainfall in the Mediterranean area, in the period 1998-2007. Results show considerable regional and seasonal differences in rainfall amounts in the examined period. Bloom et al. (2008) use regional climatic modelling to predict wind fields in the eastern Mediterranean, during the period 2071-2100. Results indicate that the mean wind speed will exhibit a general increase over land and a decrease over sea, with the exception of the Aegean Sea where a significant increase is expected. Wang et al. (2008) introduce a new canopy interception scheme to investigate the impact of sub-grid variability of precipitation and canopy water storage on climate model simulations of the water cycle in central and southern Europe. Loukas et al. (2008) estimate the expected impact of climate change on droughts in the Thessaly Region, Greece, for two socio-economical scenarios. A drought index is obtained from the Global Circulation Model predictions of precipitation for the periods 2020-2050 and 2070-2100, and compared to the estimates obtained from mean monthly precipitation records from 50 ground stations during the period 1960-1990. Time series analysis reveals an increase in drought severity for both scenarios.
A number of authors discuss the application of advanced remote-sensing techniques to observe, monitor and forecast Mediterranean storms, and their physical characteristics.

Torricella et al. (2008) study the statistical relationships between cloud-top microphysical properties derived from multispectral observations taken by the Moderate Resolution Imaging Spectroradiometer (MODIS) onboard NASA's Aqua satellite, and the corresponding rain intensity at the ground, as estimated by the operational algorithm for the Advanced Microwave Scanning Radiometer-E (AMSR-E) onboard the same satellite. Weinman et al. (2009), review the characteristics of past, current and future X-band Synthetic Aperture Radars (SAR) onboard space platforms, and discuss approaches to retrieve precipitation over land and oceans using X-band SAR data. For an event near Orléans, France, the authors compare the rainfall pattern observed by a space-borne X-band SAR with the pattern obtained by a ground-based operational radar. Alfieri et al. (2010) use rainfall measurements from a network of rain gauges to calibrate time-dependent reflectivity-rainfall rate relationships and to improve rainfall estimation from non-polarimetric groundbased radars. Barnolas et al. (2008) use a combination of rainfall measurements obtained from a dense rain gauge network, ground-based radar data, and data captured by a regional lightning detection network, to investigate a severe rainfall event that resulted in destructive flash floods in Catalonia, Spain, on 12-14 September 2006. Bonelli and Marcacci (2008) present an algorithm to track and "nowcast" thunderstorm cells using ground-based radar and lightning data, and show applications in northern Italy using data captured by a Meteo Swiss radar and by the high resolution Italian Lightning Location System. Betz et al. (2008) present the lightning detection network LINET, comprising of about 90 lightning sensors in 17 European Countries, capable of locating intra-cloud discharges and cloud-to-ground strokes with unprecedented accuracy in Europe. The authors show examples of LINET data and lightning-based cell tracking for thunderstorms in southern Germany and northern Italy. Casella et al. (2008) use the discrete dipole approximation to compute the absorption and scattering properties of randomly oriented soft-ice particles in convective clouds. Yan et al. (2008) assimilate zenith total delay observations from a network of ground-based GPS stations into a non-hydrostatic mesoscale model, to improve the quantitative rainfall forecast for a heavy precipitation event in southern France, on 5-9 September 2005.

Other authors present the results of investigations aimed at determining relationships between Mediterranean storms and surface processes, and discuss related forecasting aspects.

Sangati and Borga (2009) use high-resolution rainfall fields obtained by a ground-based radar coupled with hydrological modelling, to evaluate the sensitivity of flashflood forecasting to rainfall spatial aggregation. As a test case, the authors study an extreme flash flood in the Fella catchment, eastern Italian Alps, on 29 August 2003. 
Montesarchio et al. (2009) propose an operational methodology for the definition of critical rainfall thresholds for possible flood occurrence, and show an application to the Mignone River basin, central Italy. Manfreda (2008) proposes an analytical approach for the description of the soil-water balance and runoff generation dynamics in a humid catchment. The approach is tested in the Agri River basin, southern Italy. Rabuffetti et al. (2009) describe the operational floodforecasting system adopted by the Piemonte Region, northern Italy, founded on a fully distributed, physically based, hydrological model. Wolf (2008) discusses the physical causes of coastal flooding induced by marine storms in the UK, and reviews the mechanisms of interaction between sea waves and the mean circulation caused by wind and tides. Besides examining a case study in the Liverpool Bay, eastern Irish Sea, the author points out the importance of storm surges in the shallow water of the Northern Adriatic, where Venice is susceptible to flooding. Sánchez-Arcilla et al. (2008) examine the characterisation, both in physical and statistical terms, of wave storms along the coast of Catalonia, Spain, and review the available field data and operational wave forecasting for that region. As a conclusion, the authors discuss the implications for short-term operational forecasting and long-term climatic assessment. Lionello and Galati (2008) analyse links between significant wave height distribution in the Mediterranean Sea during the second half of the 20th century, computed using the WAM wave prediction model forced by surface winds provided by the ERA- 40 reanalysis, and the Northern Hemisphere sea level pressure teleconnection patterns derived from the NOAA Web site. Results indicate links with multiple mid-latitude patterns. Bertotti and Cavaleri (2008) study a large-wave event produced by a mistral storm between the Balearic Islands and Sardinia, western Mediterranean, on 14 February 2005. Results based on numerical modelling and experimental data indicate that the large wave that damaged the passenger cruiser "Voyager" was within the expected range of wave heights and, hence, it was not a "freak wave". Gigante et al. (2009) investigate the influence of indices for characterising the vegetation cover obtained from satellite data, on the modelling of water balance in a semi-arid catchment in southern Italy. Results indicate a significant sensitivity of the hydrological losses, and of the soil water regime, to the vegetation conditions. Caparrini and Manzella (2009) present preliminary results of the application of an integrated system for drought monitoring in Tuscany, central Italy, using meteorological data, hydrological distributed modelling, and vegetation indices obtained by processing satellite images.

Finally, the joint special issues contain papers dealing with the socio-economical implications of Mediterranean storms and their impact, including vulnerability to the population and risk management issues.

Llasat et al. (2009) investigate the impact of flash floods in Catalonia, Spain, by searching newspapers for the period 1982-2007 and compiling a database of information on natural hazards, including forest fires, droughts, floods, and rainfall events. Porcù and Carrassi (2009) use two databases of surface cyclones and cut-off lows in continental Europe, and a catalogue of damage (including casualties) derived from an insurance company record, to analyse the impact of cyclonic structures in Europe. Nicolaides et al. (2009b) use the classification presented by Michaelides et al. (2008), and investigate the impact of hailstorm events on the agricultural economy of Cyprus. Llasat et al. (2008) study the causes for changes in vulnerability to flash floods in Catalonia, Spain, and attribute the increased physical vulnerability to the population growth along the Mediterranean coast. Finally, Llasat and Siccardi (2010) examine societal and technological aspects related to flood risk management for civil protection in Italy, including uncertainties, and the limitations of the tools available to predict, forecast and measure the effects of floods affecting people and private and public properties.

Acknowledgements. We thank the EGU Council, the members of the Scientific and the Organizing Committees, and the scientists who participated to the meeting. Special thanks go to the many authors who have submitted their papers to the joint special issues of NHESS and ADGEO. We are grateful to the reviewers and the co-editors for their helpful comments and suggestions on the individual manuscripts. Their efforts have improved the quality of the two special issues. Finally, we express our gratitude to Copernicus Meetings and Copernicus Publications for their professional support.

\section{References}

Alfieri, L., Claps, P., and Laio, F.: Time-dependent Z-R relationships for estimating rainfall fields from radar measurements, Nat. Hazards Earth Syst. Sci., 10, 149-158, 2010, http://www.nat-hazards-earth-syst-sci.net/10/149/2010/.

Barnolas, M., Atencia, A., Llasat, M. C., and Rigo, T.: Characterization of a Mediterranean flash flood event using rain gauges, radar, GIS and lightning data, Adv. Geosci., 17, 35-41, 2008, http://www.adv-geosci.net/17/35/2008/.

Bertotti, L. and Cavaleri, L.: The predictability of the "Voyager" accident, Nat. Hazards Earth Syst. Sci., 8, 533-537, 2008, http://www.nat-hazards-earth-syst-sci.net/8/533/2008/.

Betz, H. D., Schmidt, K., Oettinger, W. P., and Montag, B.: Celltracking with lightning data from LINET, Adv. Geosci., 17, 5561, 2008, http://www.adv-geosci.net/17/55/2008/.

Bloom, A., Kotroni, V., and Lagouvardos, K.: Climate change impact of wind energy availability in the Eastern Mediterranean using the regional climate model PRECIS, Nat. Hazards Earth Syst. Sci., 8, 1249-1257, 2008,

http://www.nat-hazards-earth-syst-sci.net/8/1249/2008/.

Bonelli, P. and Marcacci, P.: Thunderstorm nowcasting by means of lightning and radar data: algorithms and applications in northern Italy, Nat. Hazards Earth Syst. Sci., 8, 1187-1198, 2008, http://www.nat-hazards-earth-syst-sci.net/8/1187/2008/. 
Caparrini, F. and Manzella, F.: Hydrometeorological and vegetation indices for the drought monitoring system in Tuscany Region, Italy, Adv. Geosci., 17, 105-110, 2009, http://www.adv-geosci.net/17/105/2009/.

Casella, D., Mugnai, A., Sanò, P., and Formenton, M.: Microwave single-scattering properties of randomly oriented soft-ice hydrometeors, Adv. Geosci., 17, 79-85, 2008, http://www.adv-geosci.net/17/79/2008/.

Costa, A. C., Durão, R., Pereira, M. J., and Soares, A.: Using stochastic space-time models to map extreme precipitation in southern Portugal, Nat. Hazards Earth Syst. Sci., 8, 763-773, 2008, http://www.nat-hazards-earth-syst-sci.net/8/763/2008/.

Durão, R., Pereira, M. J., Costa, A. C., Côrte-Real, J. M., and Soares, A.: Indices of precipitation extremes in Southern Portugal - a geostatistical approach, Nat. Hazards Earth Syst. Sci., 9, 241-250, 2009, http://www.nat-hazards-earth-syst-sci.net/9/241/2009/.

Fantini, M. and Malguzzi, P.: Numerical study of two-dimensional moist symmetric instability, Adv. Geosci., 17, 1-4, 2008, http://www.adv-geosci.net/17/1/2008/.

Federico, S., Avolio, E., Pasqualoni, L., and Bellecci, C.: Atmospheric patterns for heavy rain events in Calabria, Nat. Hazards Earth Syst. Sci., 8, 1173-1186, 2008, http://www.nat-hazards-earth-syst-sci.net/8/1173/2008/.

Gigante, V., Iacobellis, V., Manfreda, S., Milella, P., and Portoghese, I.: Influences of Leaf Area Index estimations on water balance modeling in a Mediterranean semi-arid basin, Nat. Hazards Earth Syst. Sci., 9, 979-991, 2009,

http://www.nat-hazards-earth-syst-sci.net/9/979/2009/.

Hashino, T.: Microphysical effects of Saharan dusts on an orogenic thunderstorm, Adv. Geosci., 17, 31-34, 2008, http://www.adv-geosci.net/17/31/2008/.

Houssos, E. E., Lolis, C. J., and Bartzokas, A.: Atmospheric circulation patterns associated with extreme precipitation amounts in Greece, Adv. Geosci., 17, 5-11, 2008, http://www.adv-geosci.net/17/5/2008/.

Lionello, P. and Galati, M. B.: Links of the significant wave height distribution in the Mediterranean sea with the Northern Hemisphere teleconnection patterns, Adv. Geosci., 17, 13-18, 2008, http://www.adv-geosci.net/17/13/2008/.

Llasat, M. C. and Siccardi, F.: A reflection about the social and technological aspects in flood risk management - the case of the Italian Civil Protection, Nat. Hazards Earth Syst. Sci., 10, 109119, 2010, http://www.nat-hazards-earth-syst-sci.net/10/109/2010/.

Llasat, M. C., Llasat-Botija, M., and López, L.: A press database on natural risks and its application in the study of floods in Northeastern Spain, Nat. Hazards Earth Syst. Sci., 9, 2049-2061, 2009, http://www.nat-hazards-earth-syst-sci.net/9/2049/2009/.

Llasat, M. C., López, L., Barnolas, M., and Llasat-Botija, M.: Flash-floods in Catalonia: the social perception in a context of changing vulnerability, Adv. Geosci., 17, 63-70, 2008, http://www.adv-geosci.net/17/63/2008/.

Loukas, A., Vasiliades, L., and Tzabiras, J.: Climate change effects on drought severity, Adv. Geosci., 17, 23-29, 2008, http://www.adv-geosci.net/17/23/2008/.
Manfreda, S.: Runoff generation dynamics within a humid river basin, Nat. Hazards Earth Syst. Sci., 8, 1349-1357, 2008, http://www.nat-hazards-earth-syst-sci.net/8/1349/2008/.

Mehta, A. V. and Yang, S.: Precipitation climatology over Mediterranean Basin from ten years of TRMM measurements, Adv. Geosci., 17, 87-91, 2008, http://www.adv-geosci.net/17/87/2008/.

Michaelides, S. C., Savvidou, K., Nicolaides, K. A., Orphanou, A., Photiou, G., and Kannaouros, C.: Synoptic, thermodynamic and agroeconomic aspects of severe hail events in Cyprus, Nat. Hazards Earth Syst. Sci., 8, 461-471, 2008, http://www.nat-hazards-earth-syst-sci.net/8/461/2008/.

Miglietta, M. M. and Regano, A.: An observational and numerical study of a flash-flood event over south-eastern Italy, Nat. Hazards Earth Syst. Sci., 8, 1417-1430, 2008, http://www.nat-hazards-earth-syst-sci.net/8/1417/2008/.

Montesarchio, V., Lombardo, F., and Napolitano, F.: Rainfall thresholds and flood warning: an operative case study, Nat. Hazards Earth Syst. Sci., 9, 135-144, 2009,

http://www.nat-hazards-earth-syst-sci.net/9/135/2009/.

Nicolaides, K. A., Michaelides, S. C., Savvidou, K., Orphanou, A., Constantinides, P., Charalambous, M., and Michaelides, M.: Case studies of selected Project "Flash" events, Adv. Geosci., 17, 93-98, 2009a,

http://www.adv-geosci.net/17/93/2009/.

Nicolaides, K. A., Photiou, G., Savvidou, K., Orphanou, A., Michaelides, S. C., Karakostas, T. S., Charalambous, D., and Kannaouros, C.: The impact of hail storms on the agricultural economy of Cyprus and their characteristics, Adv. Geosci., 17, 99-103, 2009b,

http://www.adv-geosci.net/17/99/2009/.

Porcù, F. and Carrassi, A.: Toward an estimation of the relationship between cyclonic structures and damages at the ground in Europe, Nat. Hazards Earth Syst. Sci., 9, 823-829, 2009, http://www.nat-hazards-earth-syst-sci.net/9/823/2009/.

Rabuffetti, D., Ravazzani, G., Barbero, S., and Mancini, M.: Operational flood-forecasting in the Piemonte region - development and verification of a fully distributed physically-oriented hydrological model, Adv. Geosci., 17, 111-117, 2009, http://www.adv-geosci.net/17/111/2009/.

Sánchez-Arcilla, A., González-Marco, D., and Bolaños, R.: A review of wave climate and prediction along the Spanish Mediterranean coast, Nat. Hazards Earth Syst. Sci., 8, 1217-1228, 2008, http://www.nat-hazards-earth-syst-sci.net/8/1217/2008/.

Sangati, M. and Borga, M.: Influence of rainfall spatial resolution on flash flood modelling, Nat. Hazards Earth Syst. Sci., 9, 575584, 2009, http://www.nat-hazards-earth-syst-sci.net/9/575/2009/.

Torricella, F., Cattani, E., and Levizzani, V.: Rain area delineation by means of multispectral cloud characterization from satellite, Adv. Geosci., 17, 43-47, 2008, http://www.adv-geosci.net/17/43/2008/.

Wang, D., Anagnostou, E. N., and Wang, G.: Effects of sub-grid variability of precipitation and canopy water storage on climate model simulations of water cycle in Europe, Adv. Geosci., 17, 49-53, 2008, http://www.adv-geosci.net/17/49/2008/. 
Weinman, J. A., Marzano, F. S., Plant, W. J., Mugnai, A., and Pierdicca, N.: Rainfall observation from X-band, space-borne, synthetic aperture radar, Nat. Hazards Earth Syst. Sci., 9, 77-84, 2009 ,

http://www.nat-hazards-earth-syst-sci.net/9/77/2009/.

Wolf, J.: Coupled wave and surge modelling and implications for coastal flooding, Adv. Geosci., 17, 19-22, 2008,

http://www.adv-geosci.net/17/19/2008/.

Yan, X., Ducrocq, V., Poli, P., Jaubert, G., and Walpersdorf, A.: Mesoscale GPS Zenith Delay assimilation during a Mediterranean heavy precipitation event, Adv. Geosci., 17, 71-77, 2008, http://www.adv-geosci.net/17/71/2008/. 